\title{
Geochemical and Hydrologic Considerations in Remediating Phosphorus-Contaminated Ground Water in a Sewage Plume Near Ashumet Pond, Cape Cod, Massachusetts
}

By DONALD A. WALTER and DENIS R. LeBLANC

U.S. Geological Survey

Open-File Report 97-202

Prepared in cooperation with the

NATIONAL GUARD BUREAU

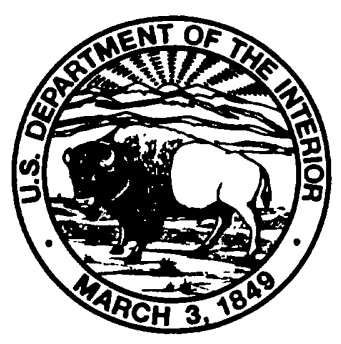

Marlborough, Massachusetts 


\title{
U.S. DEPARTMENT OF THE INTERIOR \\ BRUCE BABBITT, Secretary
}

\author{
U.S. GEOLOGICAL SURVEY \\ Gordon P. Eaton, Director
}

The use of trade or product names in this report is for identification purposes only and does not constitute endorsement by the

U.S. Geological Survey.

For additional information write to:

Chief, Massachusetts-Rhode Island District

U.S. Geological Survey

Water Resources Division

28 Lord Road, Suite 280

Marlborough, MA 01752
Copies of this report can be purchased from:

U.S. Geological Survey

Branch of Information Services

Box 25286, Federal Center

Denver, CO 80225-0286 


\section{CONTENTS}

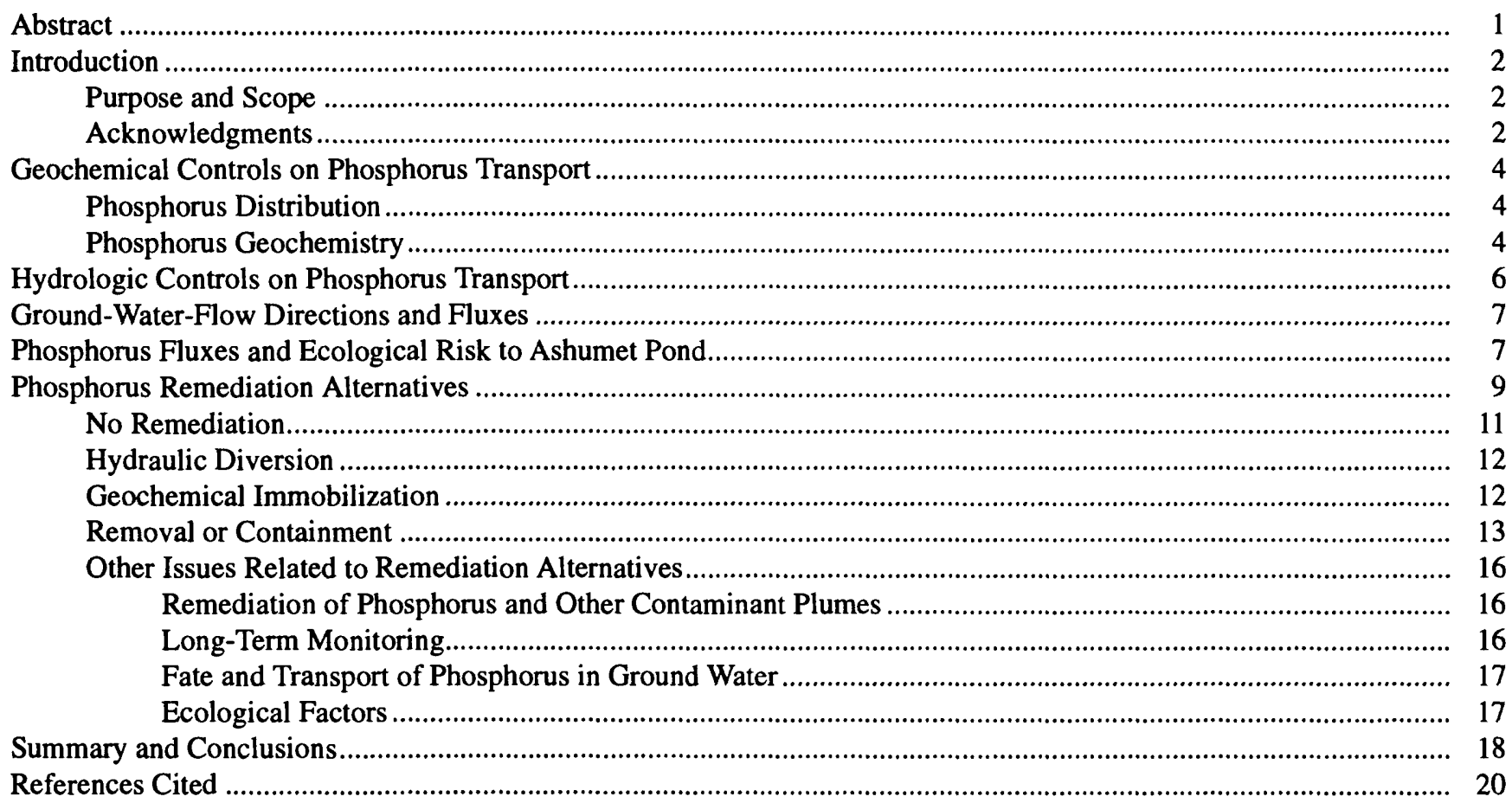

\section{FIGURES}

1-3. Map showing:

1. Location of study area near Ashumet Pond, Cape Cod, Massachusetts

2. Location of selected water-quality sampling sites, maximum phosphorus concentrations in 1993 and 1995, and the extent of the anoxic and suboxic zones in the phosphorus plume near Ashumet Pond

3. Western extent of the contributing area to Ashumet Pond for simulated pond-bottom hydraulic conductivities of 10 and 300 feet per day and the location of selected water-quality sampling sites along two vertical sections used to calculate phosphorus fluxes through the phosphorus plume near Ashumet Pond.

\section{TABLES}

1. Summary of alternatives for remediation of phosphorus-contaminated ground water near Ashumet Pond, Cape Cod, Massachusetts 
CONVERSION FACTORS, VERTICAL DATUM, WATER-QUALITY

INFORMATION, AND ABBREVIATIONS

CONVERSION FACTORS

\begin{tabular}{rcl}
\hline Multiply & By & To obtain \\
\hline cubic foot per day $\left(\mathrm{ft}^{3} / \mathrm{d}\right)$ & 0.02832 & cubic meter per day \\
foot & 0.3048 & meter \\
foot per day $(\mathrm{ft} / \mathrm{d})$ & 0.3048 & meter per day \\
acre-foot & 1233 & cubic meter \\
mile & 1.609 & kilometer \\
square mile & 12.590 & square kilometer \\
degrees Fahrenheit $\left({ }^{\circ} \mathrm{F}\right)$ & ${ }^{\circ} \mathrm{C}=5 / 9\left({ }^{\circ} \mathrm{F}-32\right)$ & degrees Celsius \\
\hline
\end{tabular}

VERTICAL DATUM

Sea level: In this report, "sea level" refers to the National Geodetic Vertical Datum of 1929 (NGVD of 1929)-a geodetic datum derived from a general adjustment of the first-order level nets of the United States and Canada, formerly called Sea Level Datum of 1929.

\section{WATER-QUALITY INFORMATION}

Chemical concentration is given in units of milligrams per liter $(\mathrm{mg} / \mathrm{L})$ or micrograms per liter $(\mu \mathrm{g} / \mathrm{L})$. Milligrams and micrograms per liter are units expressing the mass of the solute per unit volume (liter) of water. One thousand micrograms per liter is equivalent to 1 milligram per liter. Micrograms per liter is equivalent to "parts per billion." Milligrams per liter is equivalent to "parts per million."

\section{ABBREVIATIONS}

$\mathrm{kg} / \mathrm{yr} \quad$ kilograms per year

$\mu \mathrm{m} \quad$ micrometer 


\section{Geochemical and Hydrologic Considerations in}

Remediating Phosphorus-Contaminated Ground Water in a Sewage Plume Near Ashumet Pond, Cape Cod, Massachusetts

\author{
By Donald A. Walter and Denis R. LeBlanc
}

\begin{abstract}
Alternatives for remediating a phosphoruscontaminated sand and gravel aquifer near Ashumet Pond, Cape Cod, Massachusetts, to prevent ecological degradation of the pond must consider the geochemical and hydrologic processes controlling phosphorus transport in the aquifer. Disposal of secondarily-treated sewage onto sand infiltration beds at the Massachusetts Military Reservation from 1936 to December 1995 formed a plume of phosphorus-contaminated ground water that extends about 2,000 feet downgradient from the beds. The dissolved phosphorus is transported in two geochemical environments: (1) an anoxic zone, where there is no detectable dissolved oxygen and phosphorus is associated with dissolved iron, and (2) a suboxic zone, where there is low but detectable dissolved oxygen and no dissolved iron. Phosphorus in both geochemical environments is associated with a large reservoir of sorbed phosphorus. Phosphoruscontaminated ground water discharges into the pond along about 700 feet of shoreline. Field data and numerical simulations indicate that the rate of phosphorus loading to the pond was about $177 \mathrm{~kg} / \mathrm{yr}$ in 1995.
\end{abstract}

Remediation alternatives can be divided into four categories. If no remediation is implemented (category 1), phosphorus in the anoxic zone would be naturally retarded and immobilized by coprecipitation with dissolved iron as oxic conditions are reestablished in the aquifer now that sewage disposal has been discontinued.
Phosphorus in the suboxic zone would continue to desorb from aquifer sediments even though disposal has been discontinued. Ground water containing elevated levels of dissolved phosphorus from the suboxic zone may continue to dischare: to the pond for many years.

Hydraulic-diversion alternatives (category 2), such as recharge trenches, injection wells, and permeable barriers, would divert the flow of phosphorus-contaminated ground water away from the pond. These strategies may alter ground-water-flow patterns to an extent that ground-water discharge into the pond and the paths of nearby organic-solvent plumes may be adversely affected.

Geochemical-immobilization alternatives (category 3) could involve the injection of a strong oxidizing agent, such as oxygen, hydrogen peroxide, or potassium permanganate, into the anoxic zone to oxidize and precipitate dissolved iron and remove phosphorus by coprecipitation. In the suboxic zone, which is the more extensive of the two geochemical environments upgradient of the pond, these alternatives could involve the injection of ferrous iron to remove phosphorus by the same mechanism.

Large-scale remediation alternatives (category 4), such as funnel-and-gate and pumfand-treat systems, could be used to contain and treat the phosphorus plume in both geochemical environments. These systems could be combined with strategies to reduce treatment times by chemically enhancing the rate at which 
phosphorus desorbs from the sediments.

The large-scale systems could remove phosphorus by passing the contaminated water through a reactive material, such as a ferric hydroxidelimestone mixture, contained in above-ground canisters or in-ground cells.

Technical issues that remain to be addressed regarding phosphorus remediation include: (1) the need for long-term monitoring of phosphorus concentrations in the plume, (2) the validity of applying the results of laboratory experiments to the aquifer, (3) the potential effects of a remediation system on Ashumet Pond and nearby organic-solvent plumes, and (4) ecological factors that control maximum acceptable phosphorus loads to Ashumet Pond.

\section{INTRODUCTION}

A plume of sewage-contaminated ground water emanates from the Massachusetts Military Reservation (MMR) on western Cape Cod (fig. 1) as a result of nearly 60 years (1936-95) of sewage disposal onto sand infiltration beds overlying a sand and gravel aquifer (LeBlanc, 1984). Disposal to the beds ended in December 1995. Dissolved phosphorus is present in the sewage plume, at concentrations greater than $0.1 \mathrm{mg} / \mathrm{L}$, as far as $2,000 \mathrm{ft}$ downgradient from the disposal beds, or about one-eighth to one-tenth as far as conservative constituents such as boron and chloride. Phosphorus-contaminated ground water is currently (1995) discharging into nearby Ashumet Pond. There is concern that the discharge of phosphorus-contaminated ground water into the pond will accelerate the rate of algal growth and eutrophication and adversely affect the ecology of the pond. In 1993, the U.S. Geological Survey (USGS), in cooperation with the National Guard Bureau (NGB), began a multi-phase study to assess the spatial and temporal distribution of phosphorus in the sand and gravel aquifer near Ashumet Pond, to determine the hydrologic and geochemical controls on phosphorus transport from the sewage-disposal beds to Ashumet Pond, and to estimate loading rates of phosphorus into Ashumet Pond (Bussey and Walter, 1996; Stollenwerk, 1996;
Walter and others, 1996). Remediation alternatives for the phosphorus-contaminated ground water were discussed in several reports (K.V. Associates, 1991; Shanahan, 1996), but these alternatives have not been evaluated in light of recently obtained data and interpretations of phosphorus transport in the plume.

\section{Purpose and Scope}

The purpose of this report, which is in large part a synthesis of previously reported work, is to summarize the current understanding of the geochemical and hydrologic controls on phosphorus transport in the aquifer, to describe how this understanding can be used to assist in the development of a remediation strategy, and to assess the effectiveness and feasibility of previously propored remediation strategies. The report describes the distribution and geochemistry of phosphorus in ground water and in aquifer sediments. The report then discusses the advective transport of phosphorus, ground-water fluxes and flow directions, and phosphorus loading rates using numerical mode!ing and previously reported field data. Finally, in light of these physical and geochemical considerations, this current understanding of the fate and transport of phosphorus in the aquifer is used to evaluate and discuss potential remediation strategies.

\section{Acknowledgments}

Much of the discussion of potential remediation strategies, particularly geochemical alternatives, derives from a meeting of USGS researchers held in March 1996 in Boulder, Colorado. The authors thank the participants in the meeting: Douglas Kent, Roger Lee, David Parkhurst, Brigid Rea, and Kenneth Stollenwerk of the USGS National Research Program. The authors also thank Marcus Waldron of the USGS and Joyce Dickerman of Oak Ridge National Laboratory for their valuable insights into ecolorical and limnological issues related to Ashumet Pont. Discussions of phosphorus transport and remediation alternatives with Peter Shanahan of HydroAnalysis, Inc., and John Cherry and David Blowes of the University of Waterloo also were very helpful. 


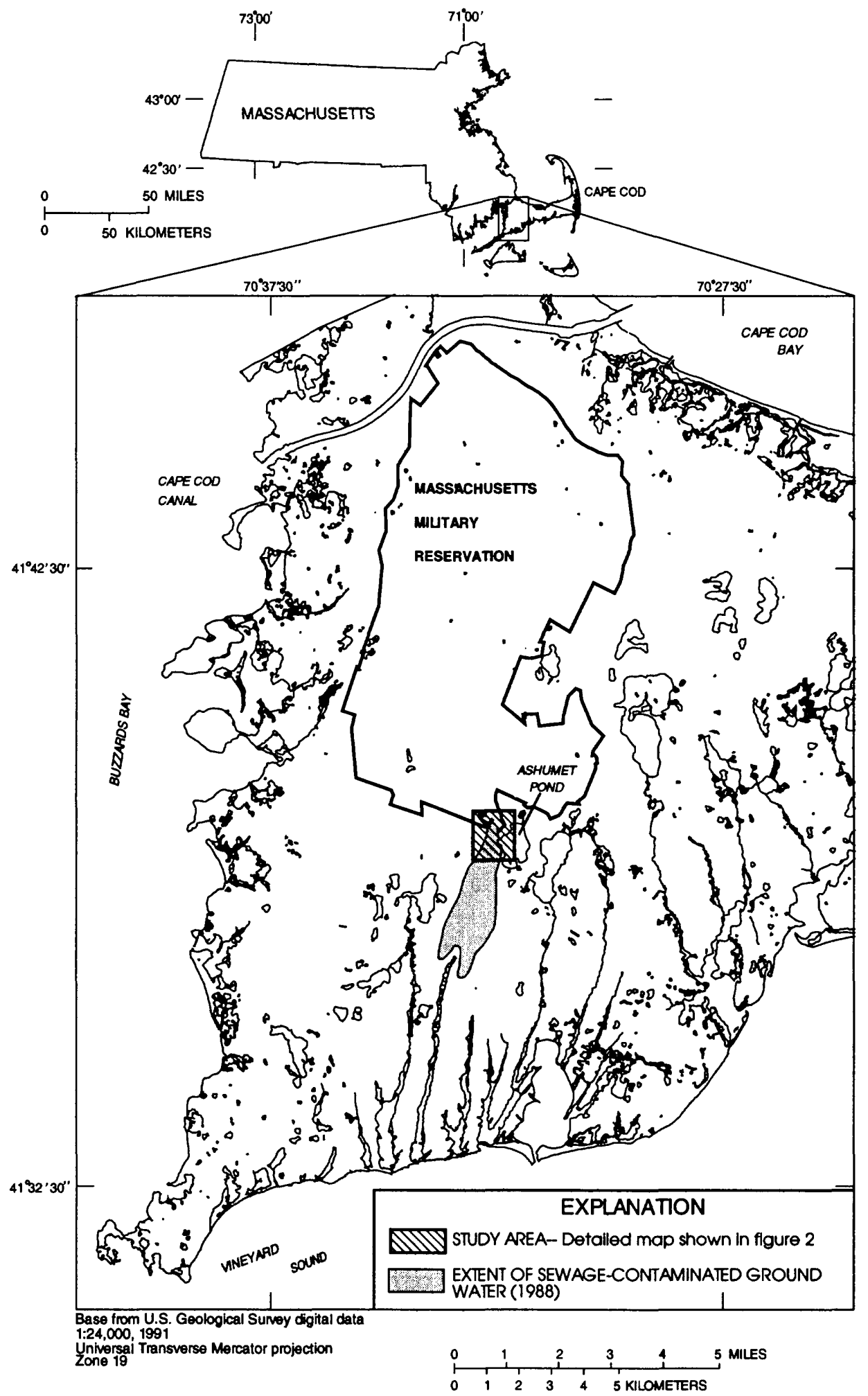

Figure 1. Location of study area near Ashumet Pond, Cape Cod, Massachusetts. 


\section{GEOCHEMICAL CONTROLS ON PHOSPHORUS TRANSPORT}

Water-quality data were collected in 1993-95 to delineate the extent of phosphorus-contaminated ground water between the sewage-disposal beds and Ashumet Pond and to assess changes in phosphorus concentrations in the aquifer with time (Bussey and Walter, 1996; Walter and others, 1996). The location of selected water-quality sampling sites, maximum phosphorus concentrations in 1993 and 1995, and the location of different geochemical environments in the plume are shown in figure 2 . In conjunction with the field sampling, laboratory column and batch experiments were conducted to investigate phosphorus sorption to aquifer sediments and to examine phosphorus transport through sediment columns under different geochemical conditions (Stollenwerk, 1996; Walter and others, 1996).

\section{Phosphorus Distribution}

Dissolved phosphorus at concentrations greater than $0.1 \mathrm{mg} / \mathrm{L}$ has been transported about $2,000 \mathrm{ft}$ downgradient from the sewage-disposal beds.

Concentrations of dissolved phosphorus were higher in the eastern part of the plume upgradient of Ashumet Pond $(6.19 \mathrm{mg} / \mathrm{L}$ in 1993 and $4.60 \mathrm{mg} / \mathrm{L}$ in 1995) than along the pond and in the center of the plume (fig. 2). Data from temporary well points driven into the pond bottom in 1993 indicate that phosphorus-contaminated ground water was discharging into Ashumet Pond along about $700 \mathrm{ft}$ of shoreline; the maximum phosphorus concentration just below the pond bottom was $1.9 \mathrm{mg} / \mathrm{L}$ (Walter and others, 1996).

Phosphorus concentrations decreased slightly in the center of the plume and showed no clear trend along the pond between 1993 and 1995; maximum concentrations along the pond were less than $2 \mathrm{mg} / \mathrm{L}$ in both years. Phosphorus concentrations in the eastern part of the plume, however, changed considerably between 1993 and 1995 (Bussey and Walter, 1996). Phosphorus concentrations at site F567 (fig. 2), for example, decreased from $6.19 \mathrm{mg} / \mathrm{L}$ in 1993 to $3.70 \mathrm{mg} / \mathrm{L}$ in 1995 (Bussey and Walter, 1996).

Interpretation of phosphorus transport based on discrete water-quality sampling rounds such as these is difficult because little historical data are available for loading rates, loading distribution, and phosphorus concentrations in the sewage effluent. However, waterquality data from the discrete sampling rounds indicate that significant temporal trends may be present in the concentrations of phosphorus and related constituents in the aquifer.

\section{Phosphorus Geochemistry}

Phosphorus transport generally is retardec relative to the rate of ground-water flow because phosphorus readily sorbs onto iron and aluminum oxide coatings on the aquifer sediments. Phosphorus in the sewage plume is mobile in two geochemical environments-an anoxic environment, where dissolved phosphorus is transported in the presence of dissolvet iron under reducing conditions, and a suboxic environment, where dissolved phosphorus is transported in the absence of dissolved iron and in the presence of dissolved oxygen in a mildly reducing (more oxidizing) environment (fig. 2). Phosphorus is transported more readily in the anoxic part of the aquifer because the abundance of iron oxide coatings that could sort phosphorus has been decreased by the reductive dissolution of the coatings. Phosphorus is transported less readily in the suboxic zone because it is strongly sorbed on the oxide coatings. Although the sorption greatly retards the average rate of phosphorus transport, elevated concentrations have reached Ashumet Pond because of the prolonged loading of phosphorus-containing effl rent at the sewage disposal beds. In effect, the prolonged loading has "used up" the capacity of the sediments to sorb additional phosphorus entering the aquifer at the concentrations characteristic of the sewage effluent, so phosphorus "breakthrough" to the pond has occurred. Phosphorus concentrations in 1993-95 were highest in the suboxic geochemical environment.

The suboxic part of the aquifer contains some dissolved manganese in addition to dissolved phosphorus at some sites. Manganese oxides can sorb phosphorus, but to a much lesser extent than iron oxyhydroxides. Therefore, manganese is probably only a minor control on phosphorus transport in the sauifer.

Chemical extractions performed on sediment cores (Walter and others, 1996) show that 95 to 99 percent of the total reservoir of phosphorus in the aquifer is sorbed onto aquifer sediments. Laboratory column experiments were used to investigate the nature of the sorbed phosphorus (Stollenwerk, 1996; Walter and others, 1996). 


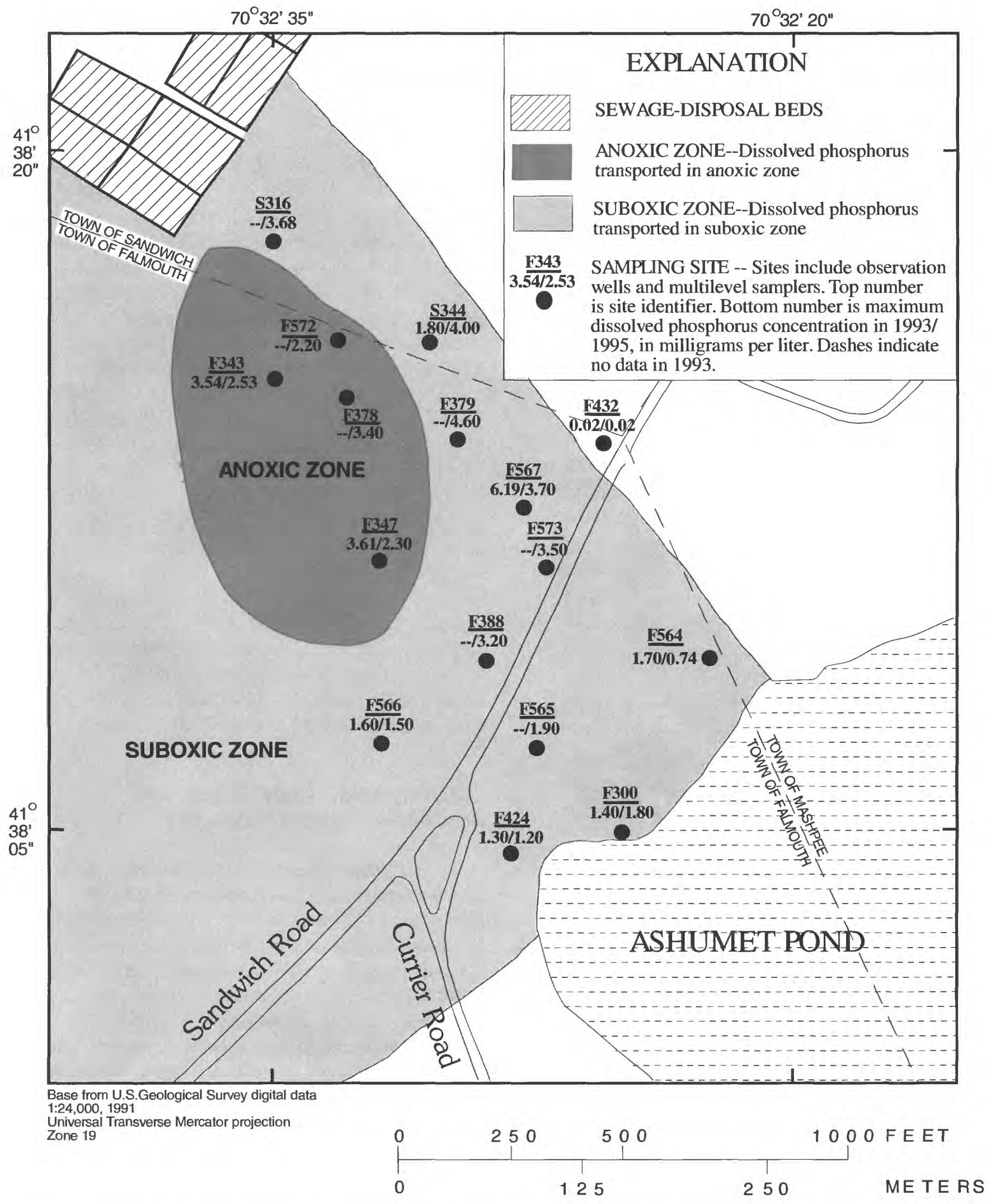

Figure 2. Location of selected water-quality sampling sites, maximum phosphorus concentrations in 1993 and 1995 , and the extent of the anoxic and suboxic zones in the phosphorus plume near Ashumet Pond, Cape Cod, Massachusetts. 
In column experiments in which clean oxic ground water was introduced into anoxic phosphorus contaminated sediment columns, phosphorus concentrations in the effluent from the columns decreased rapidly because of the oxidation of ferrous iron to ferric iron; the oxidation caused the coprecipitation of dissolved phosphorus with insoluble iron oxyhydroxide mineral phases and the sorption of dissolved phosphorus onto the fresh ferric hydroxide surfaces. The sorbed phosphorus remained immobile, presumably because it was coated with new coatings of ferric hydroxide minerals. Similar processes in the aquifer could naturally immobilize phosphorus in the anoxic zone. In column experiments in which clean oxic water was introduced into suboxic phosphorus contaminated columns, phosphorus concentrations in the effluent from the columns increased rapidly, then decreased slowly as phosphorus desorbed from the sediments. The $\mathrm{pH}$ in the columns, which was naturally buffered by aquifer sediments, also remained high, favoring the continued mobility of phosphorus. Desorption in the suboxic columns continued for many pore volumes, indicating that phosphorus concentrations could remain elevated for many years (decades) in the aquifer even though sewage disposal has ceased.

The cause of the rapid increase in phosphorus concentrations immediately after the introduction of clean oxic water into the suboxic columns is unknown. One hypothesis is that the sudden decrease in ionic strength of the influent water could have caused mobilization of phosphorus-containing colloids (Joseph Ryan, Univ. of Colorado, oral commun., 1996). Grolimund and others (1996) reported that the introduction of low ionic strength water into contaminated sediment columns caused the mobilization of colloids and facilitated the colloidal transport of lead, a strongly sorbing solute. The colloidal transport of lead was manifested by a sharp concentration peak in the column effluent, similar to the peaks observed in the phosphorus column experiments. Grolimund and others (1996) also noted that the mobilized colloids had a mean diameter of $0.01 \mu \mathrm{m}$, which is smaller than the $0.45-\mu \mathrm{m}$ pore size used to filter field samples during this investigation. Therefore, the dissolved concentrations discussed in this report may include phosphorus associated with colloids.
A second hypothesis is that the rapid increase in phosphorus concentrations in the column effluent could have been caused by rapid desorption of loosely bound phosphorus as geochemical conditions adjusted to the influx of clean water. The geochemical mechanisms that could cause phosphorus concentrations to rise above concentrations in the effluent under this scenario are unknown.

Whatever the cause of the rapid increase observed in the column experiments, there is some evidence that a similar increase has occurred in the sewage plume. High phosphorus concentrations along the eastern and western sides of the plume were associated with low to moderate specific conduct ${ }^{n}$ nces. This indicates that some influx of clean ground water had occurred in these areas. These areas are downgradient from eastern disposal beds abandoned in 1984 and western beds abandoned prior to 1975 . Therefore, high phosphorus concentrations in the eastern and western sides of the plume in 1993-95 could have resulted from the desorption of phosphorus from aquifer sediments or the mobilization of colloids following the introduction of clean ground water into previously contaminated parts of the aquifer thrc'igh natural recharge. Temporary increases in phosphorus concentrations similar to those observed along th ? eastern and western sides of the plume may occir in other sewage-contaminated parts of the aquifer $r$ w that sewage disposal has stopped altogether.

\section{HYDROLOGIC CONTROLS ON PHOSPHORUS TRANSPORT}

The flux of phosphorus into Ashumet Pond from the sewage plume is controlled not only by the distribution and geochemistry of phosphorus in the ground water, but also by the rate and direction of ground-water flow. Hydrologic data were collected in 1993 to delineate ground-water-flow directions and hydraulic gradients in the area of phosphorus contamination and to assess pond/aquifer interactions (Walter and others, 1996). A subregional model of three-dimensional ground-water flow near Ashunet Pond and the disposal beds was developed to determine the contributing area to the pond and to estimate ground-water and phosphorus fluxes into the pond.

The subregional model is nested in a larger, more coarsely discretized regional ground-water-flow model of the MMR area developed by Masterson and cthers 
(1996). Both models use the USGS numerical code MODFLOW (McDonald and Harbaugh, 1988) and the USGS particle-tracking algorithm MODPATH (Pollock, 1994). The subregional model has a finely spaced grid consisting of 185,328 cells in 12 layers. The subregional model derives its hydraulic properties and boundary conditions directly from the regional model. Because the two models are virtually identical hydraulically and differ only in the degree of discretization, separate calibration of the subregional model was not necessary.

\section{Ground-Water-Flow Directions and Fluxes}

Ground-water-flow directions and the magnitude of the hydraulic gradients are a function of water levels in the aquifer and the pond. As pond and aquifer water levels increase, the ground-water-flow direction near the phosphorus plume shifts toward the pond (eastward) and the hydraulic gradient steepens. Waterquality data from pond-bottom drive points and pondshore multilevel samplers show that the plume rises steeply at the pond shore because of strong, upward gradients near the shore (Walter and others, 1996). The discharge of phosphorus-contaminated ground water takes place mostly near the shore of the pond.

Ground-water-flow directions are generally south-southeastward, but change seasonally. Field data indicate that only a part of the phosphorus plume discharges into the pond; the remaining part passes beneath the western shore or west of the pond and continues to migrate southward. The amount of phosphorus discharging into the pond probably varies seasonally because of seasonal variations in hydraulic gradients and the volume of ground water discharging into the pond.

The subregional model was used to estimate the part of the phosphorus plume that discharges to the pond under average conditions so that prevailing geochemical conditions upgradient from the pond could be identified. The extent of the simulated contributing area to the pond is sensitive to the hydraulic conductivity of the pond bottom used in the model; the western boundary of the contributing area shifts southwestward as the simulated hydraulic conductivity of the pond bottom is increased (fig. 3). Assuming a uniform pond-bottom hydraulic conductivity of $300 \mathrm{ft} / \mathrm{d}$, which is consistent with a coarse sand and gravel pond bottom, most of the eastern half of the phosphorus plume is within the steady-state contributing area to the pond, including all of the anoxic zone and the area of high phosphorus concentrations in the eastern part of the suboxic zone. Assuming a pond-bottom hydraulic conductivity of $10 \mathrm{ft} / \mathrm{d}$, which is consistent with a silty pond bottom, only the easternmost part of the phosphorus plume is captured by the pond, including all of the area of high phosphorus concentrations in the easte'n part of the suboxic zone, but none of the anoxic zone.

The subregional model was used to estimate ground-water fluxes to Ashumet Pond from the par. of the phosphorus plume that is in the pond's contributing area. Fluxes were estimated across two vertical sections oriented transverse to flow; one section is along the pond and the other section is about $750 \mathrm{ft}$ upgradient from the pond through the eastern area of high phosphorus concentrations near site F567 (fig. 3). The thickness of the sections equals the thickness $\mathrm{c}^{f}$ the phosphorus plume at each section. The modelcalculated flux through the section along the pond ranged from $10,400 \mathrm{ft}^{3} / \mathrm{d}$ to $21,600 \mathrm{ft}^{3} / \mathrm{d}$ for pondbottom conductivities of 10 to $350 \mathrm{ft} / \mathrm{d}$. The modelcalculated flux through the upgradient section ranged from 22,000 to $24,600 \mathrm{ft}^{3} / \mathrm{d}$ for the same range of pond-bottom conductivities. Because the pond bottom near the shore is mostly sand, a flux of $20,000 \mathrm{ft}^{3} / \mathrm{d}$ at the pond shore is a reasonable "best" estimate based on present understanding of the hydrologic system.

\section{Phosphorus Fluxes and Ecological Risk to Ashumet Pond}

Phosphorus concentrations measured in 1995 and the model-calculated ground-water fluxes described above were used to estimate phosphorus fluxes through the same two sections through the part of the phosphorus plume that is captured by Ashumet Pond. Average concentrations were determined for three sampling sites on each section (fig. 3) by weighting concentrations measured at various elevations 1 ' appropriate sampling interval lengths. Average con ?entrations between sites were estimated by linear inte-polation. The ground-water fluxes used in the calculations were determined using a pond-bottom conductivity of $300 \mathrm{ft} / \mathrm{d}$ in the subregional model. The ground-waterflux estimates are the largest of those obtained from the sensitivity analysis previously described and yield the largest (or "worst case") estimates of phosphorus-f ux rates for a given set of concentrations. 


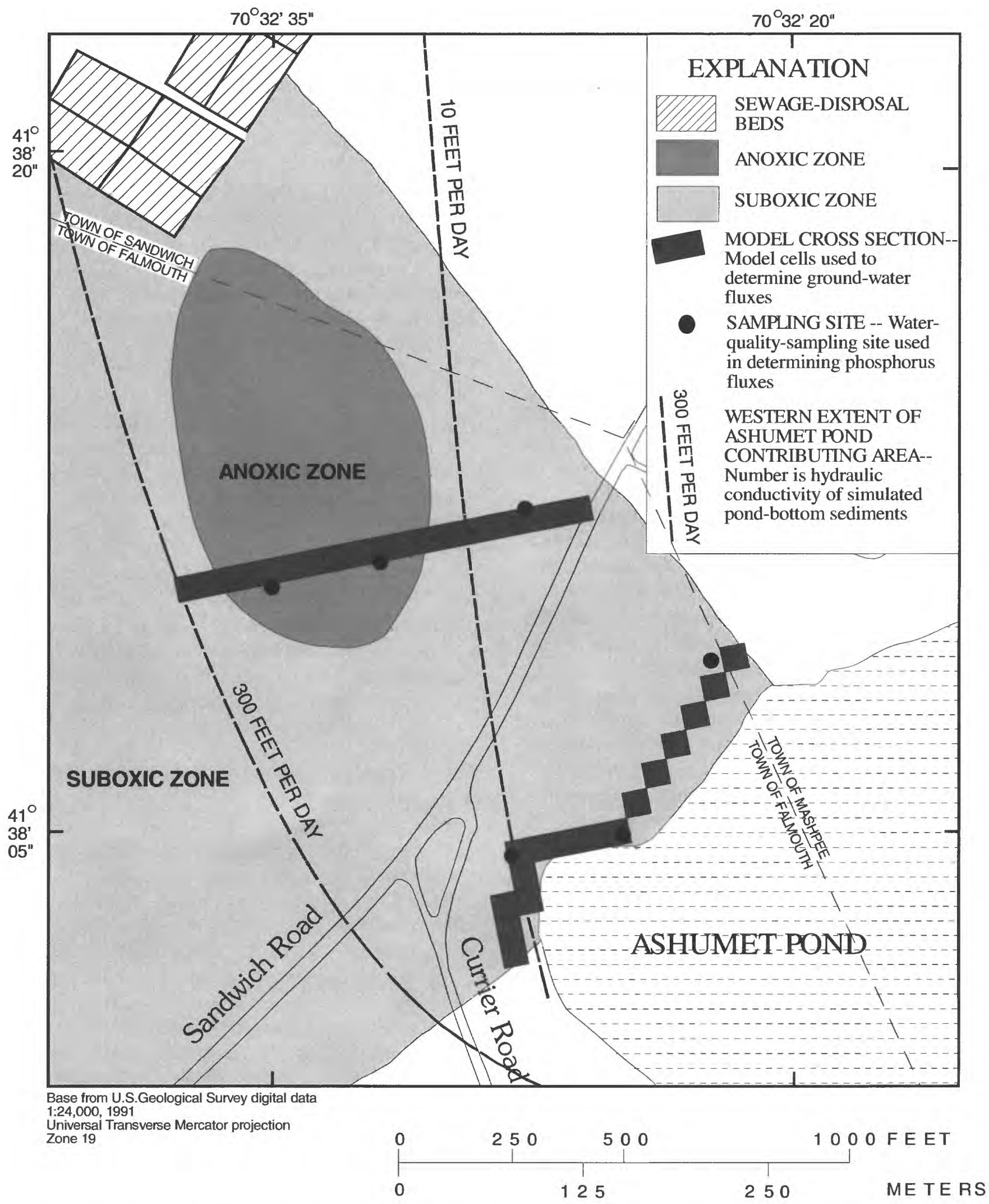

Figure 3. Western extent of the contributing area to Ashumet Pond for simulated pond-bottom hydraulic conductivities of 10 and 300 feet per day and the location of selected water-quality sampling sites along two vertical sections used to calculate phosphorus fluxes through the phosphorus plume near Ashumet Pond, Cape Cod, Massachusetts. 
The estimated annual phosphorus flux through the section along the pond is $177 \mathrm{~kg} / \mathrm{yr}$. If all this phosphorus enters the pond, the phosphorus loading rate to the pond is much larger than the rate of $37 \mathrm{~kg} / \mathrm{yr}$ reported by E.C. Jordan, Inc. (1988) and K.V. Associates (1991). The rate is also slightly larger than the rate of $172 \mathrm{~kg} / \mathrm{yr}$ reported by Walter and others (1996) from 1993 USGS field data. Processes that could decrease the loading rate by preventing some phosphorus passing through the section from entering the pond include (1) additional sorption of phosphorus on aquifer and pond-bottom sediments downgradient from the section and (2) coprecipitation of phosphorus with manganese at the pond-water/sediment interface.

The estimated phosphorus flux through the upgradient section near Sandwich Road is estimated to be about $358 \mathrm{~kg} / \mathrm{yr}$, reflecting the high phosphorus levels measured in this part of the plume. Some of the phosphorus passing through this section may not reach the pond, however, because sorption of phosphorus onto aquifer sediments between the section and the pond is likely to retard movement of the phosphorus and because part of the water passing through the section may pass west of the pond if the pond-bottom hydraulic conductivity is significantly less than 300 $\mathrm{ft} / \mathrm{d}$.

The earlier estimates of phosphorus loading rates were the basis for preliminary assessments of the ecological risk to Ashumet Pond from the phosphorus plume. Shanahan (1996) concluded that a phosphorus loading rate of $67 \mathrm{~kg} / \mathrm{yr}$ presents a significant ecological risk to the pond. He used the Vollenweider (1968) eutrophication model to calculate a steady-state phosphorus concentration in the pond water of $21 \mu \mathrm{g} / \mathrm{L}$. Vollenweider classified a lake as eutrophic if the average total phosphorus concentration in the lake water during periods of mixing exceeded $20 \mu \mathrm{g} / \mathrm{L}$.

The newly calculated phosphorus loading rate of $177 \mathrm{~kg} / \mathrm{yr}$ is about 2.5 times greater than that used by Shanahan (1996). The steady-state phosphorus concentration in the pond water using the new rate in the Vollenweider model is $35 \mu \mathrm{g} / \mathrm{L}$, which is well above the Vollenweider eutrophication limit. The new rate indicates that the phosphorus plume may pose a greater ecological risk to the pond than was predicted from the earlier estimated loading rates.

Ashumet Pond is considered to be mesotrophic based on the physiochemical characteristics of the pond (K.V. Associates, 1991); however, the pond should exhibit a higher state of eutrophication given these estimated phosphorus loading rates (Joyce Dickerman, Oak Ridge National Laborator.', written commun., 1996). Other chemical species, such as nitrogen or inorganic carbon, may control the rate of algal growth and eutrophication in the pond. In addition, ecological factors, such as algal grazing $h y$ protozoa, may enhance the ability of the pond to receive high loads of phosphorus with little degradation of the ecosystem. If the ecology of the pond is not phosphorus limited or if other factors reduce the susceptibility of the pond to eutrophication, these factors should be considered when predicting the effectiveness of a remediation strategy. A further consideration is the possible importance of seasonal cycling of phosphorus between pond sediments ant the water column in the eutrophication process (M.C. Waldron, U.S. Geological Survey, and Brian Howes, Woods Hole Oceanographic Institut:on, oral commun., 1996). This cycling, known as "internal loading," could also affect the rate of eutrophicatic 7.

\section{PHOSPHORUS REMEDIATION ALTERNATIVES}

The complicated geochemistry of phosphor's in ground water presents many challenges to remediation. Phosphorus transport is different in the two geochemical environments in the sewage plume, and more than 90 percent of the total phosphorus reser'oir is sorbed to the aquifer sediments. Now that sewage disposal has stopped, the geochemical environments and transport mechanisms are expected to change, potentially complicating the design of a remediation system. In addition, the strong effect of Ashumet Fond on local ground-water-flow patterns has direct implications for remediation.

The USGS has evaluated several remediation alternatives that have been proposed to limit or stof the discharge of phosphorus-contaminated ground water into Ashumet Pond; the alternatives are summarized in table 1. Potential ground-water remediation strategies can be divided into four categories: (1) no remediat'on, (2) hydraulic alternatives designed to alter groundwater-flow directions, (3) geochemical alternatives designed to immobilize phosphorus in specific geochemical environments, and (4) removal or containment by large-scale active or passive remediation systems, such as funnel-and-gate or pump-and-treat systems. In-lake alternatives also may be possible, but they were not evaluated as part of this study. 


\begin{tabular}{|c|c|c|c|c|c|c|c|}
\hline 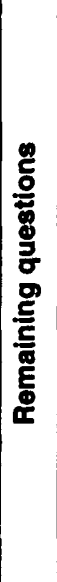 & 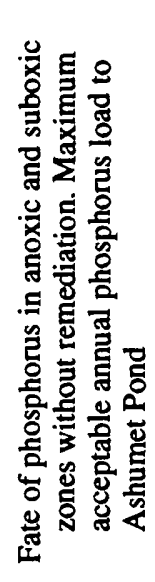 & 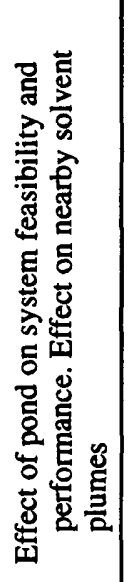 & 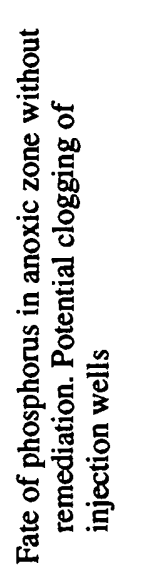 & 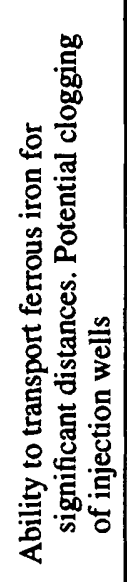 & 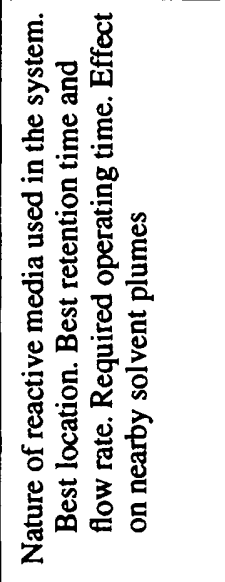 & 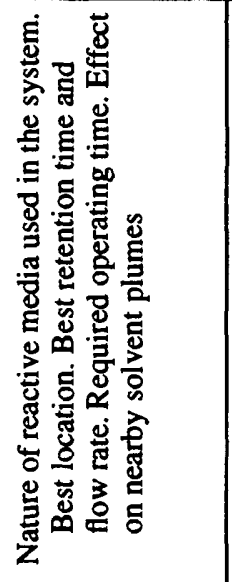 & 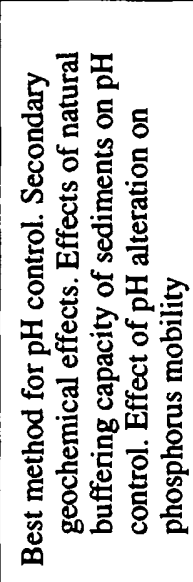 \\
\hline 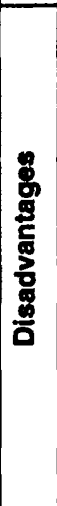 & 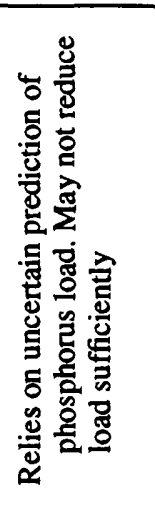 & 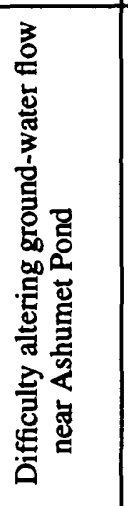 & 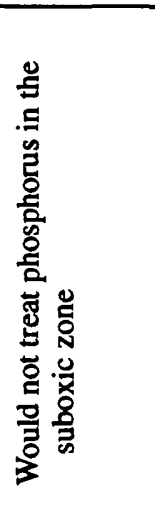 & 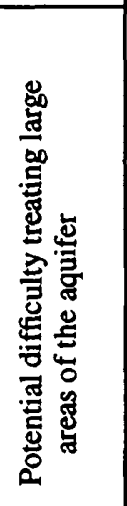 & 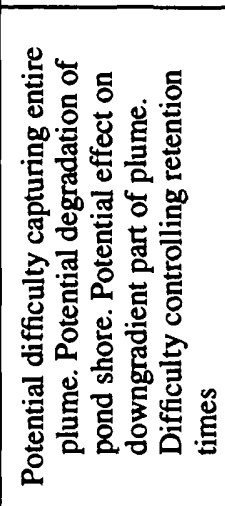 & 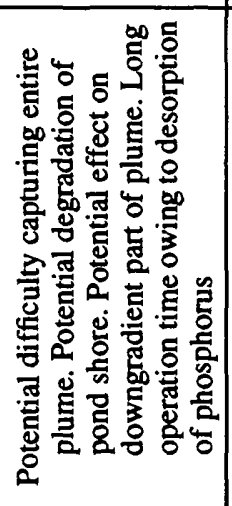 & 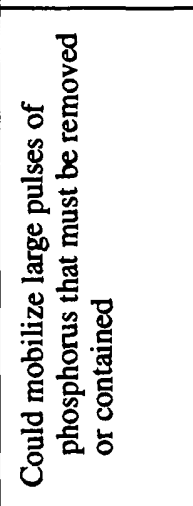 \\
\hline 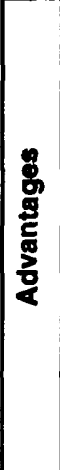 & 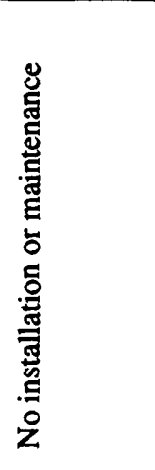 & 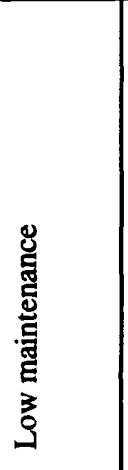 & 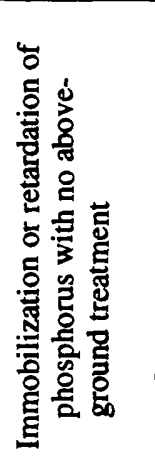 & 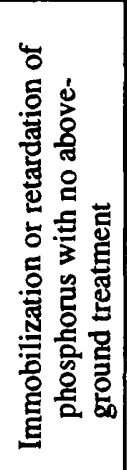 & 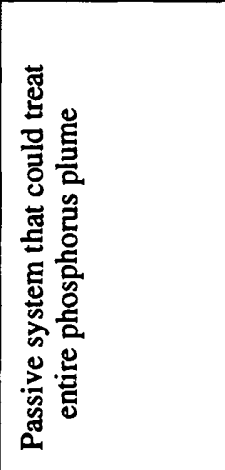 & 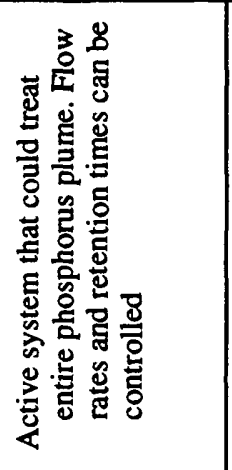 & 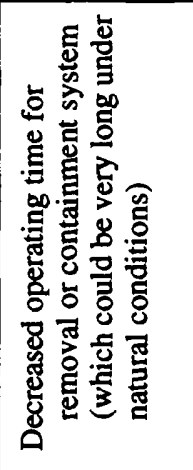 \\
\hline 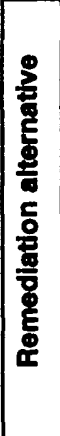 & 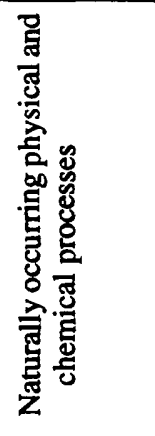 & 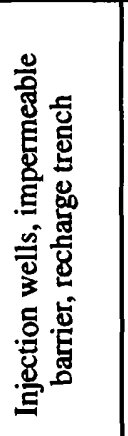 & 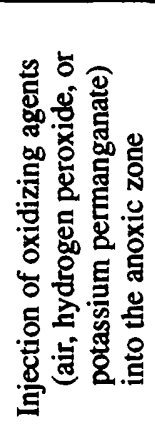 & 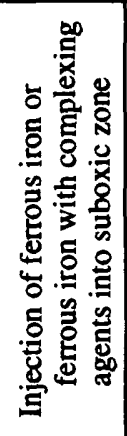 & 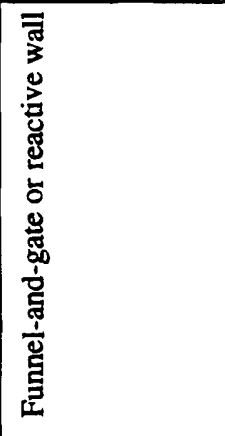 & 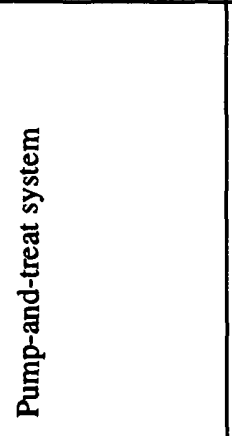 & 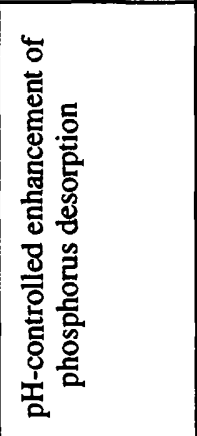 \\
\hline$\stackrel{8}{2}$ & 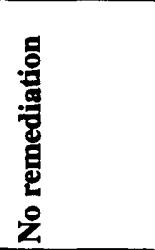 & 总总 & 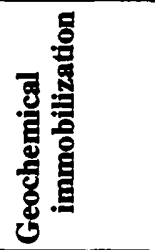 & & 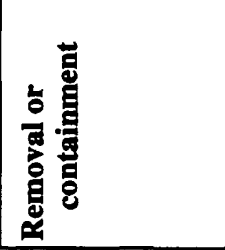 & & \\
\hline
\end{tabular}


Many of these alternatives have been discussed previously by various researchers; for example, hydraulic controls were previously discussed in Shanahan (1996) and oxidation of the anoxic zone of the phosphorus plume was discussed in K.V. Associates (1991). The remediation of phosphorus represents a unique situation at the MMR because, unlike the organic-solvent and fuel plumes, containment of the entire phosphorus plume may not be necessary; the ecological risk to Ashumet Pond is driven by loading rates and not by drinking-water standards. Before deciding on a remedial design, the maximum phosphorus loading rate that can be sustained by Ashumet Pond with no ecological degradation needs to be determined. The remediation alternatives could then be designed to reduce phosphorus loads to less than the maximum acceptable loading rate.

\section{No Remediation}

If no remediation strategy is implemented, naturally occurring geochemical processes are expected to continue to affect phosphorus concentrations in the aquifer and phosphorus loading rates into Ashumet Pond. Now that sewage disposal has been discontinued, the influx of clean, oxygenated ground water into the aquifer by natural recharge should slowly increase dissolved-oxygen concentrations, lower $\mathrm{pH}$ and specific conductance, and flush dissolved and sorbed contaminants from the aquifer. The rate of these changes is difficult to predict. For example, oxidation of the reservoir of sorbed ammonium-nitrogen and organic carbon by chemical and microbiological processes may continue to consume oxygen for some time and delay the reintroduction of oxygen into the sewage-contaminated zone. Aquifer sediments will buffer the $\mathrm{pH}$ and probably keep $\mathrm{pH}$ values in the aquifer elevated for some time. In addition, the flushing rate of some sorbing contaminants, such as phosphorus, may be very slow.

In the anoxic zone, phosphorus transport may be greatly retarded or immobilized by coprecipitation and sorption as dissolved ferrous iron is oxidized by the influx of oxygenated ground water into the aquifer. This process was observed in the laboratory column experiments by Stollenwerk (1996) described previously. The residual biological or chemical oxygen demand associated with the aquifer sediments may delay the arrival of the oxygen, however, and the anoxic zone may persist and possibly even advance. downgradient for some time. The downgradient advance of the anoxic zone probably is limited by the oxidation of ferrous iron by naturally occurring manganese oxides at the leading edge of the anoxic. zone.

Phosphorus in the suboxic zone may desorb from aquifer sediments and remain at elevated concentrations in the aquifer for many years follow'ing an influx of clean, phosphorus-free ground water. This process may already be taking place along the eastern and western sides of the plume, where elevated phosphorus concentrations are associated with low to moderate specific conductances. Based on the column experiments, phosphorus desorption or colloid mobilization, as discussed previously, may cause phosphorus concentrations in the ground water to increase sharply and remain at levels even greater than current levels for some time before slowly decreasing. In the column experiments, only 50 percent of the total reservoir of phosphorus loaded onto aquifer sediments was flushed from the columns after 50 to 80 pore volumes of clean ground water had been passed through the suboxic column, even though dissolved phosphorus concentrations in the column effluent decreased to below detection limits. Most phosphorus sorbed to aquifer sediments could eventually desorb; however, the later desorption probably will take a very long time and be associated with small concentrations and low phosphorus loading rates to Ashumet Pond.

Solute-transport modeling of phosphorus transport in the aquifer (Stollenwerk, 1996) indicates that phosphorus concentrations in ground water entering Ashumet Pond may increase during the next 10 years as water with phosphorus concentrations greater than $2 \mathrm{mg} / \mathrm{L}$ reaches the pond, then will slc "vly decrease as phosphorus is flushed from the aquifer. The solute-transport model does not reproduce the rapit increase in concentrations that was observed in the. column experiments immediately following the introduction of clean water into the contaminated sediments. Ground water having even higher phosphorus concentrations than those calculated by' the model will enter the pond if a similar concentration increase occurs in the aquifer. If phosphorus concentrations entering the pond increase in the near future, phosphorus concentrations in pond water may increase and accelerate eutrophication. For examp'e, if 
the estimated mass flux of $358 \mathrm{~kg} / \mathrm{yr}$ through the upgradient vertical section (fig. 3) should reach the pond, the Vollenweider (1968) eutrophication model predicts a steady-state phosphorus concentration in the pond of $61 \mu \mathrm{g} / \mathrm{L}$. The extent to which these high phosphorus concentrations will reach the pond and increase loading rates is unknown; however, an increase in the phosphorus loading rate for some time is possible.

\section{Hydraulic Diversion}

Hydraulic-diversion alternatives include recharge trenches, injection wells, and impermeable barriers. These hydraulic diversions are designed to divert the flow of phosphorus-contaminated ground water away from the pond. Although the phosphorus would remain in the aquifer, the diversion approach is a generally acceptable option since no other surfacewater bodies are near the pond and diverted water having elevated phosphorus concentrations is not likely to reach other surface waters. Some hydraulicdiversion alternatives, such as impermeable barriers near the pond, would require little or no maintenance.

Hydraulic-diversion alternatives have several disadvantages and complications. The plume intersects the pond in an area of significant, year-round groundwater discharge, making it potentially difficult to divert the plume away from the pond without a large change in water levels and total ground-water flow. The installation of a hydraulic-diversion alternative that would change ground-water flow patterns could cause phosphorus-contaminated ground water to discharge to other locations in Ashumet Pond. In the case of the impermeable barrier, ground-water flow may be diverted beneath the barrier, resulting in discharge into the pond farther off shore. The proximity of the phosphorus plume to the pond and the strong effect of the pond on the local ground-water-flow system further complicates the implementation of these alternatives. For example, the use of injection wells as a barrier may not be effective because water injected in wells at the pond shore could discharge to the pond with little or no change in hydraulic head in the area of the plume.

Also, large-scale shifts in ground-water-flow directions could affect nearby organic-solvent plumes (see later discussion).
The effectiveness and potentially undesirat ${ }^{-1} \mathrm{e}$ side effects of these alternatives cannot be determined without a more detailed analysis of specific designs. The subregional ground-water-flow model develc ned for the area could be used to test aspects of these hydraulic alternatives. The model could be used to evaluate (1) water-level mounding produced by pondside injection wells, (2) the effect of a pond-side impermeable barrier on ground-water-flow patterns, (3) the ability of an upgradient recharge trench to divert ground-water flow away from the pond, and (4) the sensitivity of predicted performance to assumptic ns about aquifer anisotropy and the hydraulic connertion between the pond and aquifer.

\section{Geochemical Immobilization}

Several geochemical alternatives to stop or greatly retard phosphorus transport in specific geochemical environments have been suggested. These alternatives would have no above-ground treatment. One alternative involves the injection of a strong oxidizing agent into the anoxic zone to immobilize phosphorus. The purpose would be to speed up tr? natural remediation processes in the anoxic zone previously described. Several oxidizing agents heve been proposed, including oxygen, hydrogen peroxide, and potassium permanganate. The underlying concept is that injection of a strong oxidizing agent into the anoxic part of the plume will cause the oxidation of ferrous iron, which in turn will immobilize or retard phosphorus by coprecipitation of phosphorus with ferric iron mineral phases and sorption onto "fresh" coatings of ferric hydroxide. The precipitation of new ferric iron compounds onto aquifer sediments als? could minimize future desorption of phosphorus already sorbed onto aquifer sediments. The method's effectiveness could be diminished if residual oxygen demand redepletes the dissolved oxygen after the oxidizing agent is no longer being injected and anoxic conditions are re-established. Injection of strong oxidizing agents into the anoxic zone also could cause iron-related clogging of injection-well screens.

The injection of chemical agents to oxidize. dissolved iron will not remediate phosphorus in the more extensive suboxic environment, where diss? lved oxygen is already present and there is no dissolved iron. A geochemical alternative for remediating phosphorus in the suboxic zone is the injection of a 
ferrous iron solution. As the ferrous iron disperses from the injection zone, dissolved oxygen and manganese oxides would oxidize the ferrous iron, forming insoluble iron-phosphorus minerals and ferric hydroxide coatings on aquifer sediments. This process would cause the coprecipitation of phosphorus with insoluble iron minerals and the precipitation of additional ferric hydroxide coatings onto aquifer sediments; the "fresh" coatings would prevent desorption of sorbed phosphorus from older coatings and provide new surfaces for sorption of additional dissolved phosphorus.

Given the low (but detectable) dissolved oxygen concentrations in the suboxic part of the aquifer, adding ferrous iron without additional chemical agents to enhance mobility of the iron may be possible because ferrous iron could travel several feet in the aquifer before precipitating. This alternative could be implemented by installing a line of wells upgradient of Ashumet Pond and perpendicular to the direction of ground-water flow into which a ferrous iron solution would be injected. Laboratory column experiments, small-scale field tests, and modeling would be needed to determine the optimal positions of the well screens, the concentration of ferrous iron in the injectate, and the volume of ferrous iron solution to be injected. One advantage of this approach is that the system would be inexpensive and could be implemented in a short amount of time. Several aspects of this approach would need to be investigated further, including the potential clogging of injection ports with insoluble iron minerals, the feasibility of transporting iron for a significant distance in the presence of dissolved oxygen, and the role of $\mathrm{pH}$ in controlling the transport of ferrous iron. Oxidation to ferric hydroxide is a kinetically controlled process that is dependent on a number of factors, including $\mathrm{pH}$ and to a lesser degree, the dissolved-oxygen concentration (the oxidation rate increases as both dissolved oxygen and $\mathrm{pH}$ increase).

The mobility of ferrous iron in the suboxic zone could be enhanced by injecting the ferrous iron as a ferrous-iron/ethylenediaminetetraacetic-acid (EDTA) complex. Tracer tests conducted by the USGS between the disposal beds and Ashumet Pond showed that ferric iron forms a strong complex with EDTA that does not dissociate readily in the low-pH ground water in the aquifer (Kent and others, 1992). The fate and transport of a ferrous-iron/EDTA complex should be similar to that of the ferric iron complex. If the ferrous-iron complex also does not dissociate readily, the ferrour iron would not react with dissolved oxygen and remove dissolved phosphorus from the ground water. This potential limitation needs to be investigated further before this alternative is considered. Other complexing agents, such as nitriloacetic acid (NTA), may also b : suitable based on considerations such as release rate of ferrous iron and biodegradability of the complexing agent.

\section{Removal or Containment}

Another set of alternatives involves the removal or containment of phosphorus by a large-scale passive or active remediation system. Reactive walls and funnel-and-gates are examples of passive systems, whereas pump-and-treat wells are examples of active systems. The concepts underlying both types of systems are summarized by the National Research Council (1994). These systems have several advantages: (1) Experience gained in applying simi ar technologies to remediate other contaminants in other locations could be used for this application, (2) phosphorus in the anoxic and suboxic zones of the aquifer could potentially be remediated, and (3) the system could be operated for a long period of time.

A reactive wall or funnel-and-gate system would involve the treatment of phosphorus-contaminated ground water as it passes through permeable reactivo zones or walls placed directly in the aquifer (National Research Council, 1994). A reactive wall would be a zone of reactive material, similar to a slirry wall, while a funnel-and-gate system would consist of impermeable walls that funnel the contaminated ground water through a permeable gate of reactive material. The reactive wall or funnel-and-gate system could be installed between the pond and the leading edge of the elevated phosphorus concentrations. The advantages of a passive system are the potentially simple operation and maintenance of the system ant the ability to continue treatment for a long period of time. Disadvantages of a passive remediation syste $n$ include the limited ability to control flow rates and the potential difficulty of periodically replacing the exhausted reactive materials. 
Results of the water-quality sampling in 1993-95 show that the area of highest phosphorus concentrations (greater than $3 \mathrm{mg} / \mathrm{L}$ ) does not extend southeast of Sandwich Road (fig. 2), indicating that the northwestern side of the road would be a potential location for a remediation system. Analysis of the contributing area to Ashumet Pond and water-quality data indicate that a passive system along Sandwich Road would need to be about $1,100 \mathrm{ft}$ wide and at least $80 \mathrm{ft}$ deep to capture the entire phosphorus plume; however, complete capture may not be necessary to prevent eutrophication of the pond. A system along Sandwich Road would not remediate phosphorus in ground water between the road and the pond. Also, phosphorus-free ground water produced by the system could cause desorption of sorbed phosphorus downgradient from the system and continued discharge of phosphorus-containing ground water into the pond. The ecological effects of allowing the uncaptured phosphorus to reach the pond would need to be evaluated.

A second potential location for a passive remediation system is near the shore of the pond. A passive containment system near the shore could extend from the Fishermans Cove boat landing (fig. 2) to a point about $700 \mathrm{ft}$ north of the landing; it would have to be about $60 \mathrm{ft}$ deep. This location would allow for the remediation of the entire phosphorus plume, but construction and operation of the system could cause some degradation of the shoreline.

Several questions need to be resolved before a reactive wall or funnel-and-gate system could be designed for either location, including how the system might affect ground-water-flow paths and whether it is technically feasible to install a system near Sandwich Road or along the pond. An earlier attempt to install a funnel-and-gate system in a nearby organic-solvent plume (the CS-10 plume) was abandoned because of difficulties encountered while driving the impermeable sheet piling into the ground. Although the CS-10 site has a much thicker unsaturated zone than the area near Sandwich Road, similar problems could be encountered. Plans are underway to install a reactive wall at the CS-10 source area; however, the methodology, which involves the injection of a reactive slurry of iron filings, may not be transferrable to remediation of the phosphorus plume because the reactive slurry would have different chemical ant physical properties than the CS-10 slurry and would have to be replaced periodically.

A pump-and-treat system would involve extraction of phosphorus-contaminated ground vater, removal of phosphorus by a reactive medium or chemical treatment, and reinjection of the treated water, probably near the extraction wells, to maintain a hydrologic balance in the area. Advantages of a pump-and-treat system include (1) the potential to treat phosphorus in the suboxic and anoxic environments, (2) the ability to easily replace exhausted reactive material, and (3) the ability to control flow rates and retention times within the reactive medium or chemical treatment system. Disadvantages include (1) the potential need to treat the extracted water for other contaminants, such as volatile organic compounds, and (2) the long period of extraction and treatment that may be required because phosphorus desorbs from acrifer sediments at a slow rate. Laboratory column experiments (Stollenwerk, 1996; Walter and others, 1996) indicate that a system may have to be in operation for more than 100 years.

A possible location for a line of extraction wells is along the northwestern side of Sandwich Road about $600 \mathrm{ft}$ upgradient of the pond (fig. 2). The well fence would intercept a similar width and depth as the passive system previously described. A fence at this location would present the same ecological risks associated with not capturing part of the phosphorus plume downgradient of the system and potential": causing downgradient desorption of sorbed phosphorus. Another possible location is along the pond shore. A disadvantage of a pump-and-treat system at this location is that the extraction wells could draw significant amounts of water from the pond, which would greatly reduce the system's efficiercy.

Reduction of the long extraction and treatment time would increase the attractiveness of the act ve pump-and-treat systems relative to the passive systems. One approach to reducing the long treatment time is to accelerate the rate at which phosphorus desorbs from aquifer sediments by altering the $\mathrm{pH}$ of the ground water. This approach takes advantage of the fact that the ratio of sorbed-to-dissolved phosphorus is st"ongly $\mathrm{pH}$ dependent. Experimental evidence indicates that the mobility of phosphorus and the rate of phosfhorus flushing could be enhanced by either decreasing or increasing the $\mathrm{pH}$ of the ground water. This enhanced 
mobility of phosphorus could allow the reservoir of sorbed phosphorus to be mobilized sooner and treated more quickly than under ambient $\mathrm{pH}$ conditions.

Increasing the $\mathrm{pH}$ of the ground water would increase phosphorus mobility by altering the equilibrium between the dissolved and sorbed phosphorus in the aquifer (Stollenwerk, 1996). The $\mathrm{pH}$ of the water, which is naturally buffered by the aquifer sediments, could be increased by injecting phosphorusfree water amended with lime or sodium hydroxide into the aquifer at a point upgradient, but within the capture zone, of the extraction wells. Problems associated with injection of high-pH water include (1) difficulty in maintaining high-pH conditions as low-pH recharge water flows through the aquifer, (2) secondary geochemical effects that may affect the fate of the other contaminants, and (3) increased mineral-saturation indices, which could lead to encrustation of well screens.

Decreasing the $\mathrm{pH}$ might be a better option for enhancing phosphorus mobility than increasing the $\mathrm{pH}$. Low-pH water would enhance phosphorus mobility by recrystallizing the iron and aluminum oxide coatings that represent most of the available phosphorus sorption sites in the aquifer. As these coatings recrystallize, loosely bound phosphorus would be desorbed, and phosphorus would flush from the aquifer more quickly than under ambient $\mathrm{pH}$ conditions. Low$\mathrm{pH}$ conditions would be easier to maintain and pose fewer problems from secondary geochemical effects. The $\mathrm{pH}$ could be decreased by injecting water treated with carbon dioxide.

An inherent risk in the $\mathrm{pH}$-alteration approaches is that a large pulse of phosphorus would be produced, and it would be imperative that the pulse be captured by the extraction wells. In a recently conducted column experiment, an increase of $\mathrm{pH}$ using sodium bicarbonate significantly enhanced phosphorus desorption; phosphorus concentrations in water discharging from the column decreased to detection limits much more rapidly than under natural-pH conditions (K.G. Stollenwerk, U.S. Geological Survey, oral commun., 1996); however, about 40 pore volumes of flushing were still required before phosphorus concentrations decreased to below detection limits. A second column experiment is planned to test the effect of a decrease in $\mathrm{pH}$ on phosphorus desorption. Also, the effect of an artificial increase or decrease in $\mathrm{pH}$ on the ability of a reactive material or chemical process in a treatment system to remove the desorbed phosphorus from solution would need to be evaluated.

A second approach to reducing the long treatment time is to immobilize or retard the phosphorus using one of the geochemical alternatives previously discussed at a location upgradient of a large-scale containment or removal system. The upgradient immobilization of phosphorus would decrease the concentration of phosphorus entering a containment system near the pond so that acceptable, phosphorus loading rates could be reached more quickly and treatment stopped sooner than if a containment system were used alone.

Passive and active systems could involve the treatment of phosphorus using a reactive medium, for example, one that would sorb phosphorus and remove it from solution. Several questions need to be addressed regarding the reactive material, including (1) the ability of the material to remove phosphoru from solution for different influent concentrations and flow rates, (2) the capacity (or storage potential) of the material to sorb phosphorus at different concentrations, and (3) the effect of changing redox conditions and $\mathrm{pH}$ on the performance of a reactive medium. The sorption of phosphorus may be a kinetically controlled proc?ss, and a minimum retention time of phosphoruscontaminated ground water in the reactive material would be needed. In addition, the reactive medium would have a finite capacity to sorb and store phosphorus, so the material would need to be repla?ed periodically. A sorptive medium, such as ferric hydroxide or a porous alumina, could potentially remediate phosphorus in the suboxic and anoxic parts of the aquifer. Anoxic water could cause some reductive dissolution of a ferric hydroxide medium that would lessen the ability of the material to sorb phosphorus. Porous alumina could be used as the reactive material because it has a high reactive surface area, moderate particle size, and thermodynamic stability in oxidizing and reducing conditions. A mixture of ferric hydroxide and limestone also could be used as the reactive medium (Baker, 1993). This material removes phosphorus by precipitation of an insoluble calcium-phosphorus mineral phase and b:" sorption of excess dissolved phosphorus onto ferric hydroxide. In column experiments conducted at the University of Waterloo, the material removed phosphorus from water that had an influent phosphorus 
concentration of $3.5 \mathrm{mg} / \mathrm{L}$ for more than 130 pore volumes (David Blowes, University of Waterloo, oral commun., 1996).

The effectiveness of a containment or removal system would be best evaluated by monitoring phosphorus loading rates instead of concentrations. If a remediation system is placed upgradient of the pond, possibly along Sandwich Road (fig. 2), phosphorus concentrations in ground water near the pond shore could be monitored and converted to loading rates using model-calculated ground-water fluxes. If the remediation system is along the pond, monitoring of the performance of the system would be more difficult because it might require monitoring ground water beneath the pond bottom.

\section{Other Issues Related to Remediation Alternatives}

Several other issues related to phosphorus transport and remediation that should be considered are (1) the interaction between a phosphorus remediation strategy and the potential fate and remediation of two nearby organic-solvent plumes, (2) long-term monitoring of phosphorus and related water-quality constituents, (3) the fate and transport of phosphorus in ground water as hydrologic and geochemical conditions in the aquifer change, and (4) ecological factors, such as the role of phosphorus in limiting algal growth in Ashumet Pond and the contribution of phosphorus recycling in the pond to the pond's phosphorus budget.

\section{Remediation of Phosphorus and Other Contaminant Plumes}

Any remediation strategy for phosphorus may have to account for the potential discharge of two nearby organic-solvent plumes into Ashumet Pond and the possible interception of solvent-contaminated water by a phosphorus-plume containment system. The subregional ground-water-flow model was used to simulate the hydrologic effects of the cessation of sewage disposal on ground-water-flow paths between the disposal beds and the pond. Prior to the cessation, the sewage plume was underlain along its eastern side by an organic-solvent plume emanating from a firetraining area (FTA-1) located to the north of the disposal beds (ABB Environmental Services, 1995).
Model simulations indicate that, following cessation, the path of the FTA-1 plume may pass through tr ? present location of the overlying phosphorus plume, and a part of the FTA-1 plume may discharge into Ashumet Pond in the absence of the water-table mounding caused by sewage disposal. Therefore, the remediation strategy for the phosphorus plume should consider the fate of the FTA-1 plume. Several fartors may already limit the potential threat of the FTA-1 plume to the pond; contaminated soil at FTA-1 has been removed, and concentrations of solvents in the FTA-1 plume near the source are less than $100 \mu \mathrm{g} / \mathrm{L}$ (Edward Pesce, MMR Installation Restoration Program, oral commun., 1996). In addition, the presence of a large, residual biomass beneath the former sewage-disposal beds may result in natural biodegradation of the organic compounds before they reach the treatment system or the pond.

The subregional numerical model also was used to determine the effects on the phosphorus plume of a plume-containment system that had been proposed for another nearby organic-solvent plume, known as the CS-10 plume (Operational Technologies Corporation, 1996). The design specified 39 extraction wells that would have withdrawn 120 to 200 gallons per minute per well, for a total yield of $5,560 \mathrm{gal} / \mathrm{min}$. The extraction wells would have been screened from 30 to $180 \mathrm{ft}$ below sea level, much deeper than the phosphorus plume, which ranges in depth from $40 \mathrm{ft}$ above to $30 \mathrm{ft}$ below sea level. The model simulations showed that the proposed design would have pulled down and fully captured the phosphorus plume. If this design had been implemented, a phosphorus trea'ment system could have been added to the CS-10 system. The design was not implemented, however, beca'sse of its negative ecological effects on Ashumet Pond, where predicted drawdown of the pond level exceeded $6 \mathrm{ft}$. Other remediation alternatives are presently being considered for the CS-10 plume (James Snyder, MMR Installation Restoration Program, oral commun., 1996); all of these strategies should consider potsntial interactions between the phosphorus plume and roarby organic-solvent plumes.

\section{Long-Term Monitoring}

Continued monitoring of the concentratiors of phosphorus and related constituents would indicate how geochemical conditions in the aquifer are changing now that sewage disposal has stopped, and 
would aid assessment of how these changes might affect remediation plans. Field and laboratory data show that phosphorus concentrations in the aquifer can change rapidly, particularly in response to the influx of clean ground water into the aquifer. Several wells and multilevel samplers are being sampled periodically as part of a USGS study of natural aquifer restoration following sewage-disposal cessation (Hess and others, 1996); however, these sampling sites are located mostly in or near the former sewage-disposal beds. This monitoring could be expanded to include several additional sites between the disposal beds and the pond. Samples for phosphorus and related constituents, such as dissolved oxygen, $\mathrm{pH}$, iron, manganese, and boron, could be collected from these sites on a quarterly or semiannual basis. In addition, since the FTA-1 organic-solvent plume could migrate through phosphorus-contaminated parts of the aquifer, it would also be prudent to monitor organic solvents at several sites between the FTA-1 source area and the pond.

\section{Fate and Transport of Phosphorus in Ground Water}

Much of our current understanding of phosphorus transport is based on laboratory experiments. Small-scale field tests are required to test the validity of applying results of these laboratory experiments to the aquifer. The existing USGS tracertest research site, located between the disposal beds and Sandwich Road, contains dense multilevel-sampler arrays in the anoxic and suboxic parts of the phosphorus plume that could be used for these tests. For example, tracer experiments could be used to field test (1) the effect of injecting treated water back into the sewage plume on other contaminants, (2) the acceleration of phosphorus desorption from aquifer sediments by altering the $\mathrm{pH}$ of the ground water, and (3) the feasibility of injecting ferrous iron or a ferrousiron/EDTA complex to immobilize phosphorus in the suboxic zone. Small-scale field tests also could be used to examine the fate of phosphorus when clean, oxygenated ground water naturally enters or is injected into the anoxic and suboxic parts of the aquifer. The effectiveness and practicality of reactive media for phosphorus removal in a funnel-and-gate or pump-andtreat system also could be tested in the field. Such a test could include an extraction-injection well pair with an in-line, above-ground canister containing a reactive medium, such as the ferric hydroxide-limestone mixture being studied at the University of Waterloo.
Aspects of the use of reactive media that could be tested include the ideal retention time of phosphoruscontaminated ground water in the medium and the capacity of the material to remove phosphorus for different phosphorus concentrations, $\mathrm{pH}$, and redox conditions.

Numerical modeling is an excellent tool to address additional remediation issues. Specific designs for a funnel-and-gate or pump-and-treat system could be tested with the USGS subregional model. Hydraulic aspects of specific systems that can be examined by modeling include (1) the extent of the capture zone, (2) the effect on local ground-water-flow patterns, ground-water and pond levels, (3) ground-water flures to Ashumet Pond, and (4) the sensitivity of a system's predicted performance to the hydraulic connection between the pond and aquifer. Ground-water modeling also could be used to test the feasibility of hydraulically diverting the phosphorus plume away from the pond. Solute-modeling of phosphorus transport in the aquifer could help improve predictions of future phosphorus loads to Ashumet Pond.

\section{Ecological Factors}

The maximum acceptable annual phosphorus load that Ashumet Pond can receive with no ecologi :al degradation must be determined to design an effective phosphorus remediation system. The eutrophication models used previously to assess ecological risk do not address seasonal internal cycling of phosphorus in the pond. If external loading is small compared to the internal load, it is possible that eutrophication could continue unabated even after capture and remediation of the phosphorus plume. Pond-bottom sediment data, including data on the phosphorus content of pond sediments collected as part of the ecological baseline study being conducted for the MMR Installation Restoration Program (IRP), could help address this question. In addition, factors other than phosphorus loads, such as nitrogen and inorganic carbon concentrations, may limit algal growth in the pond, and biological or biochemical processes may be taking place in the pond that limit its susceptibility to eutrophication (Joyce Dickerman, Oak Ridge National Laboratory, written commun., 1996). Based on thes? considerations, limnologists and ecologists might be able to suggest and evaluate alternative or complementary in-lake remediation strategies. 


\section{SUMMARY AND CONCLUSIONS}

Phosphorus-contaminated ground water (phosphorus concentrations greater than $0.1 \mathrm{mg} / \mathrm{L}$ ) has moved as far as $2,000 \mathrm{ft}$ downgradient from the recently abandoned sewage-disposal beds at the Massachusetts Military Reservation and discharges into nearby Ashumet Pond along about $700 \mathrm{ft}$ of shoreline. The maximum phosphorus concentration in pore-water samples collected just below the pond bottom in 1993 was $1.9 \mathrm{mg} / \mathrm{L}$. Phosphorus concentrations as high as $6.19 \mathrm{mg} / \mathrm{L}$ were detected in ground water between the disposal beds and Ashumet Pond; the area of highest concentrations is upgradient of the pond near the eastern side of the plume.

Dissolved phosphorus is transported in two geochemical environments in the sewage plume: (1) an anoxic zone, where there is no dissolved oxygen and phosphorus is transported in the presence of dissolved iron; and (2) a suboxic zone, where there is low but detectable dissolved oxygen and no dissolved iron. In the suboxic zone, phosphorus, although strongly sorbed to the iron oxide coatings, has moved as far as Ashumet Pond because of the long period of sewage disposal ( 60 years). The dissolved phosphorus in both zones is associated with a large reservoir of sorbed phosphorus. In 1995, only phosphorus in the suboxic environment was discharging into Ashumet Pond.

About $177 \mathrm{~kg} / \mathrm{yr}$ of phosphorus was estimated to be discharging into Ashumet Pond in 1995. This loading estimate would increase to about $358 \mathrm{~kg} / \mathrm{yr}$ if the high phosphorus concentrations observed northwest of Sandwich Road are not reduced by sorption onto aquifer sediments before reaching the pond. Both of these estimates are based on the largest model-calculated ground-water fluxes and assume that all phosphorus at the sampling sites upgradient of the pond eventually will enter the pond. Using a loading rate of $177 \mathrm{~kg} / \mathrm{yr}$ in the Vollenweider eutrophication model, the steady-state phosphorus concentration in Ashumet Pond is estimated to be $35 \mu \mathrm{g} / \mathrm{L}$. Vollenweider classified a lake as eutrophic if the average total phosphorus concentration in the lake water during periods of mixing exceeded $20 \mu \mathrm{g} / \mathrm{L}$.

Remediation to limit or stop phosphorus loading from the plume into Ashumet Pond can be divided into four categories: (1) no remediation, (2) hydraulic diversion to alter ground-water-flow patterns,
(3) geochemical immobilization of phosphorus in specific geochemical environments, and (4) removal or containment of phosphorus by large-scale passive or active remediation systems.

If no remediation strategies are implemen ${ }^{+e}$, naturally occurring physical and geochemical processes will continue to affect future phosphorus loading to Ashumet Pond. Phosphorus concentrations in ground water entering Ashumet Pond from th: suboxic environment could increase during the next 10 years if the area of elevated concentrations northwest of Sandwich Road reaches the pond. In the suboxic part of the aquifer, elevated levels of dis'olved and colloidal phosphorus also could result if the large reservoir of sorbed phosphorus desorbs and collinids are mobilized in response to the influx of uncontaminated ground water now that sewage disposal has been discontinued. Laboratory column experiments and field data indicate that this proress may already be taking place along the sides of the plume. Phosphorus concentrations in the aquifer could remain higher than current levels at the pond for a number of years, and phosphorus could continue to desorb from aquifer sediments for decades. In th 9 anoxic zone, phosphorus transport may be greatly retarded within a few years by coprecipitation with dissolved iron when uncontaminated, oxygenated water eventually reenters the sewage-contaminated parts of the aquifer.

Hydraulic-diversion alternatives include recharge trenches, injection wells, and imperme able barriers. These systems would divert the flow of phosphorus-contaminated ground water away from the pond. These alternatives may be difficult to imp'ement because of the strong effect of the pond on groundwater-flow patterns and the potential for altering the paths of nearby organic-solvent plumes.

Geochemical-immobilization alternatives generally involve the injection of chemical ager's into specific geochemical environments to immobilize or greatly retard phosphorus transport. An alternat:ve for remediating phosphorus in the anoxic zone is to inject an oxidizing agent to oxidize dissolved ferrous iron and, thus, coprecipitate phosphorus with insolut'le. ferric iron oxide minerals; possible oxidizing agents include oxygen, potassium permanganate, and hydrogen peroxide. This method would not remadiate 
phosphorus in the suboxic part of the aquifer because phosphorus in that environment is not transported in the presence of dissolved iron. An alternative to immobilize phosphorus in the suboxic part of the aquifer is to inject ferrous iron so that phosphorus would be coprecipitated with ferric iron mineral phases and also would be sorbed onto "fresh" coatings of ferric hydroxide. The ability to transport ferrous iron for substantial distances in the plume under the redox and $\mathrm{pH}$ conditions typical of the suboxic environment may limit the feasibility of this approach; dispersal of ferrous iron could be enhanced using complexing agents, such as EDTA and NTA.

Large-scale passive or active remediation systems, such as a funnel-and-gate (passive) or pumpand-treat system (active) system, could be used to contain and remediate the phosphorus plume. An advantage of these systems is their potential to remediate phosphorus in both geochemical environments. A pump-and-treat system has the additional advantage of controlled flow rates and retention times through the treatment process, but the system may have to be operated for a long period of time because of the slow flushing rate of sorbed phosphorus from the aquifer. The slow flushing rate of sorbed phosphorus could be accelerated by altering the $\mathrm{pH}$ of the ground water. The best alternative may be to decrease the $\mathrm{pH}$, possibly using carbon dioxide, to recrystallize iron and aluminum oxide coatings in the aquifer and mobilize loosely bound phosphorus.

A phosphorus-containment system about $600 \mathrm{ft}$ upgradient of the pond would contain the area of highest phosphorus concentrations in the plume, but it would not contain phosphorus between the system and the pond and could induce the desorption of phosphorus downgradient of the system. A location along Ashumet Pond would contain the entire phosphorus plume, but construction and operation could involve some degradation of the pond shore, and the hydraulic design might be difficult because of the proximity of the pond.

These systems could use a reactive medium for the removal of phosphorus; one possibility is a ferric hydroxide and limestone mixture. Important issues to address concerning the use of any reactive material include the required retention time of phosphoruscontaminated ground water in the material, the ability and capacity of the material to remove phosphorus, and the effects of different water chemistries on the performance of the material.

Any remediation strategy for the phosphorus plume should consider the fate of the nearby FTA-1 and CS-10 organic-solvent plumes. Computer model simulations indicate that part of the FTA-1 plume adjacent to the phosphorus plume may move through the phosphorus-contaminated part of the aquifer and discharge into Ashumet Pond. A phosphorus containment system could potentially intercept orge nic solvents from this plume.

Regardless of the remedial approach, continued monitoring of phosphorus and related constituents would indicate how geochemical conditions and the path of the FTA-1 plume are changing now that sewage disposal has been discontinued, and how these changes might affect remediation plans. This monitoring could be combined with ongoing USGS monitoring near the sewage disposal beds by adding sampling sites between the beds and Ashumet Pond.

Small-scale tracer tests could be used to address issues such as (1) the effect of uncontaminated ground water that will eventually re-enter the area of the plime on phosphorus desorption and transport, (2) the effect of low- or high-pH water on phosphorus mobility, and (3) the performance of reactive media under different field conditions. Numerical modeling could be used to evaluate hydrologic aspects of specific remediation designs, including (1) capture zones, (2) effects on local ground-water-flow patterns and plume paths, and (3) the interaction between proposed systems and Ashumet Pond.

The maximum acceptable phosphorus load th at Ashumet Pond can receive with no ecological degradation must be known to design an effective remediation system. Ecological analysis of the phosphorus budget of Ashumet Pond would help address the questions that remain concerning the role of internal phosphorus loading from the pond-bottc $m$ sediments on eutrophication and the role of other chemical and biological factors, such as nitrogen and inorganic carbon concentrations, in limiting algal growth in the pond. Based on these considerations, limnologists and ecologists might be able to suggest and evaluate in-lake remediation strategies. 


\section{REFERENCES CITED}

ABB Environmental Services, Inc., 1995, Ashumet Valley ground water operable unit remedial investigations report, Massachusetts Military Reservation, Cape Cod, Massachusetts (Draft): Oak Ridge, Tenn., Hazardous Waste Remedial Actions Program (HAZWRAP), April 1995, variously paged.

Baker, M.J., 1993, Laboratory investigations into the potential for solid mixtures containing industrial products to remove phosphates from solution: Waterloo, Ontario, Department of Earth Sciences, University of Waterloo, unpublished B.S. thesis, $39 \mathrm{p}$.

Bussey, K.W., and Walter, D.A., 1996, Spatial and temporal distribution of specific conductance, boron, and phosphorus in a sewage-contaminated aquifer near Ashumet Pond, Cape Cod, Massachusetts: U.S. Geological Survey Open-File Report 96-472, 44 p.

E.C. Jordan, Inc., 1988, Ashumet Pond trophic state eutrophication control assessment-Task 1-4, Final report: Oak Ridge, Tenn., Hazardous Waste Remedial Actions Program (HAZWRAP), March 1988, $101 \mathrm{p}$.

Grolimund, D., Barkovec, M., Barmetler, K., and Stiches, H., 1996, Colloid-facilitated transport of strongly-sorbing contaminants in natural porous media: a laboratory column study: Environmental Science and Technology, v. 30, no. 10, p. 3118-3123.

Hess, K.M., LeBlanc, D.R., Kent, D.B., and Smith, R.L., 1996, Natural restoration of a sewage-contaminated aquifer, Cape Cod, Massachusetts, in Hydrology and hydrogeology of urban and urbanizing areas, the proceedings of the conference, Boston, Mass., April 2124, 1996: Minneapolis, Minnesota, American Institute of Hydrology, p. WQE13-WQE25.

Kent, D.B., Davis, J.A., Rea, B.A., and Anderson, L.D., 1992, Ligand-enhanced transport of strongly sorbing metal ions in the ground-water environment, in Kahara, Y., and Maest, A., eds., Water-Rock Interaction WRI-7: Rotterdam, Netherlands, Balkema, v. 1, p. 805-808.

K.V. Associates, 1991, Ashumet Pond, Falmouth/Mashpee, Massachusetts-A diagnostic/feasibility study: Falmouth, Mass., K.V. Associates and IEP, Inc., 158 p.

LeBlanc, D.R., 1984, Sewage plume in a sand and gravel aquifer, Cape Cod, Massachusetts: U.S. Geological Survey Water-Supply Paper 2218, 28 p.
Masterson, J.P., Walter, D.A., and Savoie, Jennifer, 1996, Use of particle tracking to improve numerical model calibration and to analyze ground-water flow ant contaminant migration, Massachusetts Military Reservation, western Cape Cod, Massachusetts: U.S. Geological Survey Open-File Report 96-214, 50 p.

McDonald, M.G., and Harbaugh, A.W., 1988, A mod'slar three-dimensional finite-difference ground-wate- flow model: U.S. Geological Survey Techniques of V'aterResources Investigations, book 6, chapter A1, $5^{>} 6 \mathrm{p}$.

National Research Council, 1994, Alternatives for ground water cleanup: Washington, D.C., National Academy Press, $315 \mathrm{p}$.

Operational Technologies Corporation, 1996, Installation Restoration Program, Plume Containment Desig? Analysis Plan, Massachusetts Military Reservation, Cape Cod, Massachusetts (Draft): San Antonio, Texas, Operational Technologies Corporation, January 1996, variously paged.

Pollock, D.W., 1994, User's guide for MODPATH/ MODPATH-PLOT, version 3-A particle tracking post-processing package for MODFLOW, the U.S. Geological Survey finite-difference ground-water flow model: U.S. Geological Survey Open-File Report 94-464, variously paged.

Shanahan, Peter, 1996, Effect of the MMR sewage pl'me on the present and potential future health of Ashurret Pond: Acton, Mass., HydroAnalysis, Inc., 65 p.

Stollenwerk, K.G., 1996, Modeling phosphorus transาort in sewage-contaminated groundwater, Cape Cod, Massachusetts: Applied Geochemistry, v. 11, p. 317-324.

Vollenweider, R.A., 1968, The scientific basis of lake and stream eutrophication with particular reference to phosphorus and nitrogen eutrophication factors: Pari? France, Organization for Economic Cooperatior and Development, Technical Report DA/DSI/68-27, 182 p.

Walter, D.A., Rea, B.A., Stollenwerk, K.G., and Savoie, Jennifer, 1996, Hydrologic and geochemical controls on phosphorus transport in a sewagecontaminated sand and gravel aquifer near Ashumet Pond, Cape Cod, Massachusetts: U.S. Geological Survey Water-Supply Paper 2463, $89 \mathrm{p}$. 